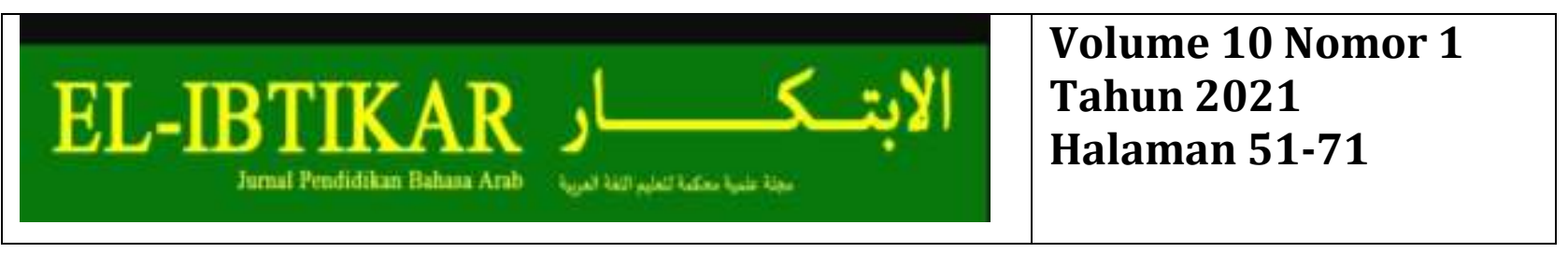

\title{
Analisis Kesalahan Sintaksis dan Morfologi pada Video Lomba Debat Bahasa Arab
}

\author{
Ahmad Hafidz Abdullah \\ Universitas Islam Negeri (UIN) KH. Ahmad Shiddiq Jember \\ Email: Ahmadhafidz893@gmail.com \\ Ana Fitriyana \\ Universitas Islam Negeri (UIN) KH. Ahmad Shiddiq Jember \\ Email: anafitriyanamrajj@gmail.com \\ Muhammad Alfan \\ Universitas Negeri Malang \\ Email: muhammadalfan99@gmail.com
}

Diterima artikel: 22 Februari 2021

Diterbitkan artikel: 16 Juni 2021

\section{Abstract}

Debat can help students to see the power of rationality, reasons of argumentation, and proof in action. This is possible that thay explain their point of view in using the rethorical. These can built the calmness and self-confidence. Seeing, organizing, and serving the information in an interasting way. This research is proposed to describe and explore some kinds of mistake in Arabic Speaking Skill in debat by an analysis of syntax and morphology mistakes and this research also gives the solution of such mistakes. This research uses the qualitative approach in mistakes on Vidios of Arabic Debating of National or ASEAN level. The results of this research are; 1) there are 29 mistakes on syntax and 12 mistakes on morphology, 2) the solutions of it can be; a) there needs a preparation for deabaters to learn about syntax and morphology language aspect, b) there should be an excercise continously, c) there should be the seriousness to develop the Arabic deabating.

Keywords: Debating Arab, Morfologis, Sintaksis

\begin{abstract}
Abstrak
Debat dapat membantu peserta didik untuk melihat kekuatan penggelaran rasional, argumen beralasan dan bukti kuat dalam tindakan. Ini memungkinkan mereka menjelaskan sudut pandang mereka dengan memanfaatkan kefasihan retoris. Ini juga menanamkan rasa sangat tenang dan percaya diri. meneliti, mengorganisir, dan menyajikan informasi dengan cara yang menarik. Penelitian ini bertujuan untuk mendiskripsikan dan mengeksplor bentuk kesalahan ucap dalam keterampilan berbicara di bidang debat bahasa Arab berupa analisis kesalahan siktaksis dan morfologi serta memberikan solusi untuk mengatasi problema kesalahan ucap debat bahasa Arab. Penelitian ini menggunakan pendekatan analisis isi kualitatif terhadap kesalahan pada video lomba debat bahasa Arab tingkat nasional maupun ASEAN. Hasil penelitian ini adalah: (1) terdapat 29 kesalahan sintaksis dan 12 kesalahan morfologi (2) Solusi yang ditawarkan adalah: (a) perlunya
\end{abstract}


persiapan debaters dalam aspek sintaksis dan morfologi, (b) melakukan latihan berkesinambungan, dan (c) meningkatkan keseriusan mendalami debat bahasa Arab.

Kata Kunci: Debat Bahasa Arab, Morfologi, Sintaksis

\section{ملخص}

تساعد المناظرة الطلاب على رؤية قوة تقديم الحجج المنطقية والعقلانية و البراهين والأدلة القوية في العمل. لأنها تمكنهم

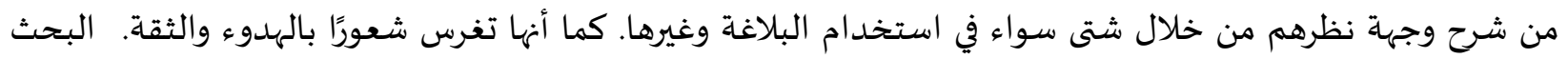
عن المعلومات وتنظيمها وتقديمها بطريقة جذابة. تهدف هذه الدراسة العلميّة إلى وصف واسه واستكشاف شكل أخطاء الكلام في

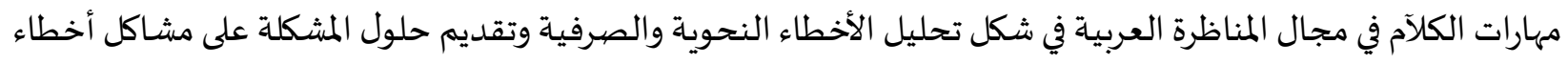
الكلآم في المناظرة العربية. تستخدم هذه الدراسة نهج تحليل المحتوى النوعي للأخطاء في فيديوهات مسابقة مناظرات اللغة العبية على المستوى الوطني ومستوى الآسيان. نتائج هذه الدراسة هي: (1) هناك 29 أخطاء نحوي و 12 أخطاء مورفولوجي (2) الحلول المقدمة من هذه المشكلآت هي: (أ) على المناظرين ان تستعدوا إستعدادا جيّدا في الجوانب المدان النحوية

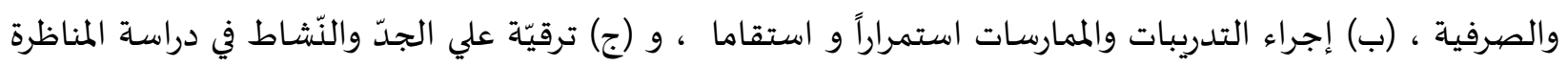

\section{Pendahuluan}

Bahasa Arab adalah salah satu bahasa yang dipelajari di Indonesia, dan sekaligus sebagai bahasa kedua. Sebagai bahasa kedua, bahasa Arab masih dianggap "sulit" oleh para pengkajinya, meskipun mayoritas penduduk Indonesia adalah muslim dan kitab sucinya adalah al-Qur"an yang berbahasa Arab. Kesulitan menggunakan bahasa Arab disebabkan bahasa Arab dan bahasa Indonesia adalah dua bahasa yang tidak sama, baik dari segi fonologi, morfologi dan sintaksisnya.

Di dalam bahasa Arab terdapat 4 keterampilan dasar, yaitu: keterampilan menyimak (al-istimā'), berbicara (al-kalām), membaca (al-qirā'ah), dan menulis (alkitābah). Berbicara tentang keterampilan berbicara (al-kalām), Dewasa ini metode yang sering dibicarakan adalah debat bahasa Arab, debat bahasa Arab sering disebut sebagai salah satu wasilah untuk melejitkan kemampuan berbahasa Arab, dan termasuk strategi pembelajaran kalam yang efektif. Kiblat yang di ambil dalam pengajaran metode debat bahasa Arab ini adalah Qatar Debate Center (QDC) yang merupakan anggota Qatar Foundation for Education, Education and Community Development, yang mulai dirilis pada tahun 2008, dan menjadi bagian organisasi debat Nasional Qatar. Tujuannya adalah membentuk masyarakat global hari ini, dan menjadi intelektual pemimpin esok. 
Tujuan $Q D C$ adalah untuk menghasilkan siswa berkualifikasi tinggi, kompetitif, dan mahir, unggul dalam masyarakat multibahasa, multikultural, dan global. Tugas Foundation ini di sekolah dan universitas meliputi lokakarya debat untuk siswa, juga berusaha untuk mengarusutamakan gagasan debat sebagai kegiatan ekstrakurikuler yang menyeluruh. Dengan keberagaman manfaat dari Yayasan ini, $Q D C$ berharap agar sekolah dan universitas mulai mempertimbangkan pentingnya perdebatan sebagai subjek dan life skill itu, karena secara signifikan debat dapat meningkatkan kemampuan siswa untuk berkomunikasi dengan lebih baik, memberi informasi, dan secara aktif berkontribusi pada perkembangan masyarakat mereka. Sebagai sebuah organisasi, $Q D C$ juga melayani masyarakat dengan bermitra dengan organisasi dan kementerian lokal untuk meningkatkan kualitas diskusi publik melalui program debat publik. Program ini menawarkan platform informasi dan konstruktif bagi organisasi untuk memberdayakan kaum muda dan meningkatkan kesadaran akan pentingnya isu lokal dan isu global di forum terbuka.(Jannah: 2016)

Di antara event yang menggunakan metode debat bahasa Arab tersebut adalah event Unisi Arabic Debating Championship yang di selenggarakan oleh Universitas Islam Indonesia Jogjakarta. Di Universitas tersebut terdapat organisasi yang berkaitan dengan pembelajaran 4 maharah bahasa Arab. Sebagai event yang sangat di dambakan oleh kalangan debater bahasa Arab tingkat mahasiswa, sejauh ini masih ada penyimpangan kebahasaan yang terjadi ketika perlombaan berlangsung. Hal ini menarik perhatian untuk peneliti untuk meneliti kesalahan-kesalahan yang terjadi di event tersebut. Karena, para peserta yang mengikuti perlombaan tersebut bisa disebut "expert" dalam penguasaan keterampilan berbicara tersebut. Peneliti mengambil beberapa sample video debat mahasiswa tingkat nasional dan ASEAN dari youtube .

Tujuan penelitian dalam artikel ini adalah menganalisis dan mendeskripsikan kesalahan berbahasa pada konteks sintaksis dan morfologi pada video debat bahasa Arab dari youtube tingkat nasional dan ASEAN. Dengan adanya penelitian ini diharapkan agar para debaters dapat selalu mengevaluasi diri dan untuk lebih mempersiapkan diri dalam aspek sintaksis dan morfologi.

Terdapat 3 artikel hasil penelitian terdahulu yang terkait dengan penelitian \# (penelitian siapa), yaitu (1) analisis Kesalahan Sintaksis dalam buku teks bahasa arab 
untuk perguruan tinggi agama Islam (Suharto and Fauzi: 2017), (2) analisis kesalahan gramatikal teks terjemah (Indonesia-arab) dalam pendidikan bahasa arab (Fahmi: 2015), (3) analisis kesalahan fonologis dalam keterampilan berbicara (Wulandari: 2020).

Perbedaan penelitian (penelitian siapa, misal penelitian ini, atau penelitian sekarang dll) dengan tiga penelitian tersebut adalah terletak pada objek yang diteliti. Pada penelitian objek yang diteliti adalah video debat bahasa Arab, sedangkan pada tiga penelitian tersebut yang diteliti adalah buku teks arab, teks tugas terjemah (Indonesia-arab) dan pengucapan tutor (pengajar). Adapun persamaannya adalah pada aspek yang diteliti yaitu sama-sama meneliti kesalahan sintaksis, morfologi dan keterampilan berbicara.

\section{Metode Penelitian}

Penelitian Analisis Kesalahan Debat Bahasa Arab pada event lomba nasional maupun ASEAN tingkat mahasiswa merupakan jenis penelitian deskriptif kualitatif dengan pendekatan analisis isi terhadap kesalahan berbahasa. Data penelitian ini berupa data kualitatif yang bersumber dari video debat bahasa Arab mahasiswa dalam lomba tingkat nasional maupun ASEAN. Data yang kami pilih merupakan data perlombaan yang merujuk pada para debaters yang dianggap benar-benar memahami konteks dunia debat bahasa arab yang berjumlah 16 video, selanjutnya data akan dikumpulkan dengan teknik mencatat kesalahan yang ada untuk menganalisis faktor penyebab terjadinya kesalahan. berikut link video yang akan kami teliti yang

\begin{tabular}{|c|c|c|c|c|c|}
\hline No & Link Video & $\begin{array}{c}\text { Tahu } \\
n\end{array}$ & No & Link Video & Tahun \\
\hline 1 & $\frac{\text { https://youtu.be/Bd5Uo tE- }}{\underline{\mathrm{mA}}}$ & 2012 & 9 & $\frac{\underline{\text { https://youtu.be/Qyx8TzWJp }}}{\underline{08}}$ & 2018 \\
\hline 2 & $\frac{\text { https://youtu.be/SrtWIwTMU }}{\underline{w Y}}$ & 2014 & 10 & $\frac{\text { https://youtu.be/RyVANyOxj }}{\underline{N w}}$ & 2018 \\
\hline 3 & https://youtu.be/OrxigBs3jPk & 2015 & 11 & $\frac{\text { https://youtu.be/JkwZ09JPdP }}{\underline{0}}$ & 2019 \\
\hline 4 & https://youtu.be/M5InYfn1i6Y & 2017 & 12 & $\frac{\text { https://youtu.be/Z6PHFq fst }}{\underline{Y}}$ & 2019 \\
\hline 5 & https://youtu.be/at1UIAfHad4 & 2017 & 13 & $\frac{\text { https://youtu.be/6TxzwsE3q }}{\underline{x 0}}$ & 2019 \\
\hline
\end{tabular}




\begin{tabular}{|c|c|c|c|c|c|}
\hline 6 & $\underline{\text { https://youtu.be/q397JnIIxSg }}$ & 2018 & 14 & $\frac{\text { https://youtu.be/1Czi Q fNg }}{\underline{E}}$ & 2019 \\
\hline 7 & $\frac{\text { https://youtu.be/Ow7cxFHm0 }}{\underline{\text { RQ }}}$ & 2018 & 15 & $\frac{\underline{\text { https://youtu.be/kjeJnOqh6 }}}{\underline{\text { w4 }}}$ & 2019 \\
\hline 8 & $\frac{\text { https://youtu.be/thF3oWApFZ }}{\underline{Y}}$ & 2018 & 16 & $\frac{\text { https://youtu.be/V- }}{\text { 1ur02gazg }}$ & 2020 \\
\hline
\end{tabular}

\section{Pengertian Analisis Kesalahan}

Ellis (1987), mendefinisikan analisis kesalahan berbahasa sebagai suatu prosedur yang digunakan oleh para peneliti dan para guru yang mencakup pengumpulan sampel bahasa pelajar, pengenalan kesalahan-kesalahan yang terdapat dalam kesalahan tersebut, pendeskripsian kesalahan-kesalahan itu, pengklasifikasiannya berdasarkan sebabsebabnya yang telah dihipotesiskan, serta pengevaluasian keseriusannya. Sedangkan Tarigan (1996) dan Lilis (1997), analaisis kesalahan berbahasa adalah suatu prosedur kerja yang biasa digunakan oleh peneliti atau guru bahasa, yang meliputi kegiatan pengumpulan sampel kesalahan, mengidentifikasi kesalahan yang terdapat dalam sampel, menjelaskan kesalahan tersebut, mengklasifikasikan kesalahan itu, dan mengevaluasi taraf keseriusan kesalahan itu. (Salim: 2016)

Adapun tujuan analisis kesalahan berbahasa menurut Corder memiliki dua tujuan yaitu : tujuan teoritis dan tujuan praktis. Senada dengan Corder, Tarigan mengatakan bahwa tujuan dari analisis kesalahan berbahasa itu bersifat aplikatif dan teorits. Aplikatif mengurangi dan memperbaiki kesalahan berbahasa siswa. Teoritis mengharapkan pemerolehan bahasa siswa yang pada gilirannya dapat memberikan pemahaman ke arah pemerolehan bahasa secara umum. Terlepas dari itu analisis kesalahan berbahasa yang dilakukan oleh seorang guru atau peneliti dapat membantu mengidentifikasi kesalahan dan penyebabnya sehingga dapat merubah metode atau teknik mengajar yang digunakan dan menjadi acuan dalam merencanakan pembelajaran bahasa. (Haniah: 2018).

\section{Pengertian Debat Bahasa Arab}

Keterampilan berbicara adalah kemampuan mengungkapkan bunyi-bunyi artikulasi atau kata-kata untuk mengekspresikan pikiran berupa ide, pendapat, keinginan, atau perasaan kepada lawan bicara. (Amriani dan Hardianto Rahman: 2020) Berbicara 
merupakan suatu aktivitas berbahasa kedua yang digunakan oleh manusia dalam kehidupan bahasa setelah mendengarkan. Bunyi-bunyi yang telah ia dengar menjadikannya belajar mengucapkan dan pada akhirnya digunakan untuk berbicara. Keterampilan berbicara sangat penting dalam kehidupan sehari-hari karena dengan berbicara manusia bisa menyampaikan isi pikirannya sehingga dapat berkomunikasi antara satu dengan yang lainnya. Seperti dalam firman Allah SWT dalam Al-Qur'an surat An-nisa' ayat 63.

Keterampilan berbicara juga berkaitan erat dengan proses berpikir dalam dasar berbahasa. Maka, semakin seseorang terampil dalam berbahasa, maka semakin jelas pula jalan pemikirannya. (Siska Setianingsih: 2020) Keterampilan berbahasa dapat diperoleh dan digunakan dengan cara praktek dan banyak Latihan. Maka dari itu, semua orang dapat melatih keterampilan bahasanya sehingga dapat mengembangkan cara berfikir dan berkomunikasi dengan baik dan benar khususnya dalam keterampilan berbicara. Begitu juga dalam bahasa asing seperti dalam bahasa Arab, jika seseorang ingin bisa berbicara bahasa Arab dengan baik, makai ia harus memperbanyak Latihan.

Sedangkan debat (perhatikan kesalhan penggunaan huruf kapital, ini bukan judul makalah atau judul buku) bahasa Arab sendiri adalah salah satu strategi pembelajaran bahasa Arab yang masuk pada tatanan metode komuniaktif (Ath- thoriqoh Al-Ithisholiyah). Menurut Ahmad Fuad Effendy Metode komunikatif memiliki keunggulan dibandingkan metode-metode yang lain: Pertama, metode ini dianggap efektif untuk meningkatkan kemahiran berbahasa Aktif. Kedua, Metode ini cocok untuk memotivasi mahasiswa, siswa atau santri yang terus meningkatkan kemahiran bahasa aktifnya. Ketiga, suasana yang tercipta dari proses pembelajaran semacam ini biasanya sangat positif, penuh gairah, kompetitis dan jauh dari membosankan (Ibnu Burdah: 2016)

Adapun manfaat debat dalam sudut pandang Qatar Debate Center membuktikan bahwa manfaat yang dibawanya sangat banyak. Debat dapat memberikan pengalaman kondusif untuk mengubah hidup, kognitif, dan keterampilan presentasi. Sebagai tambahan, melalui debat seseorang akan memperoleh manfaat pendidikan yang unik saat mereka belajar dan memoles keterampilan jauh melampaui apa yang bisa dipelajari dalam sudut pandang lainnya. Paling tidak, debat membantu peserta didik untuk melihat kekuatan 
penggelaran rasional, argumen beralasan dan bukti kuat dalam tindakan. Ini memungkinkan mereka menjelaskan sudut pandang mereka dengan memanfaatkan kefasihan retoris. Ini juga menanamkan rasa sangat tenang dan percaya diri. meneliti, mengorganisir, dan menyajikan informasi dengan cara yang menarik. (1) meningkatkan kepercayaan, ketenangan, dan harga diri peserta didik, (2) menyediakan aktivitas yang menarik, aktif, dan berpusat pada peserta didik, (3) meningkatkan ketepatan tatanan dan kemampuan berpikir kritis yang tinggi, (4) meningkatkan kemampuan untuk menyusun dan mengatur pemikiran, (5) meningkatkan riset analitis, penelitian, dan pencatatan, (6) meningkatkan kemampuan peserta didik untuk membentuk argumentasi, informasi dan penggunaan yang seimbang dan penalaran dan bukti, (7) mengembangkan komposisi dan penyampaian pidato yang efektif, dan (8) mendorong kerja tim. (Jannah: 2016).

Ada 3 aspek yang dinilai dalam debat bahasa arab, yaitu :

a. Skill Bahasa, mencakup keselarasan bahasa dan ketepatan bahasa.

b. Isi/ Argumen meliputi kesesuaian hujjah dengan tema debat, ketuntasan pembahasan, kualitas gagasan, logika dan keaslian pemikir, kesinambungan gagasan antar anggota dan kerjasama.

c. Adab mencakup kesantunan, volume suara dan bahasa tubuh. (Jannah: 2017)

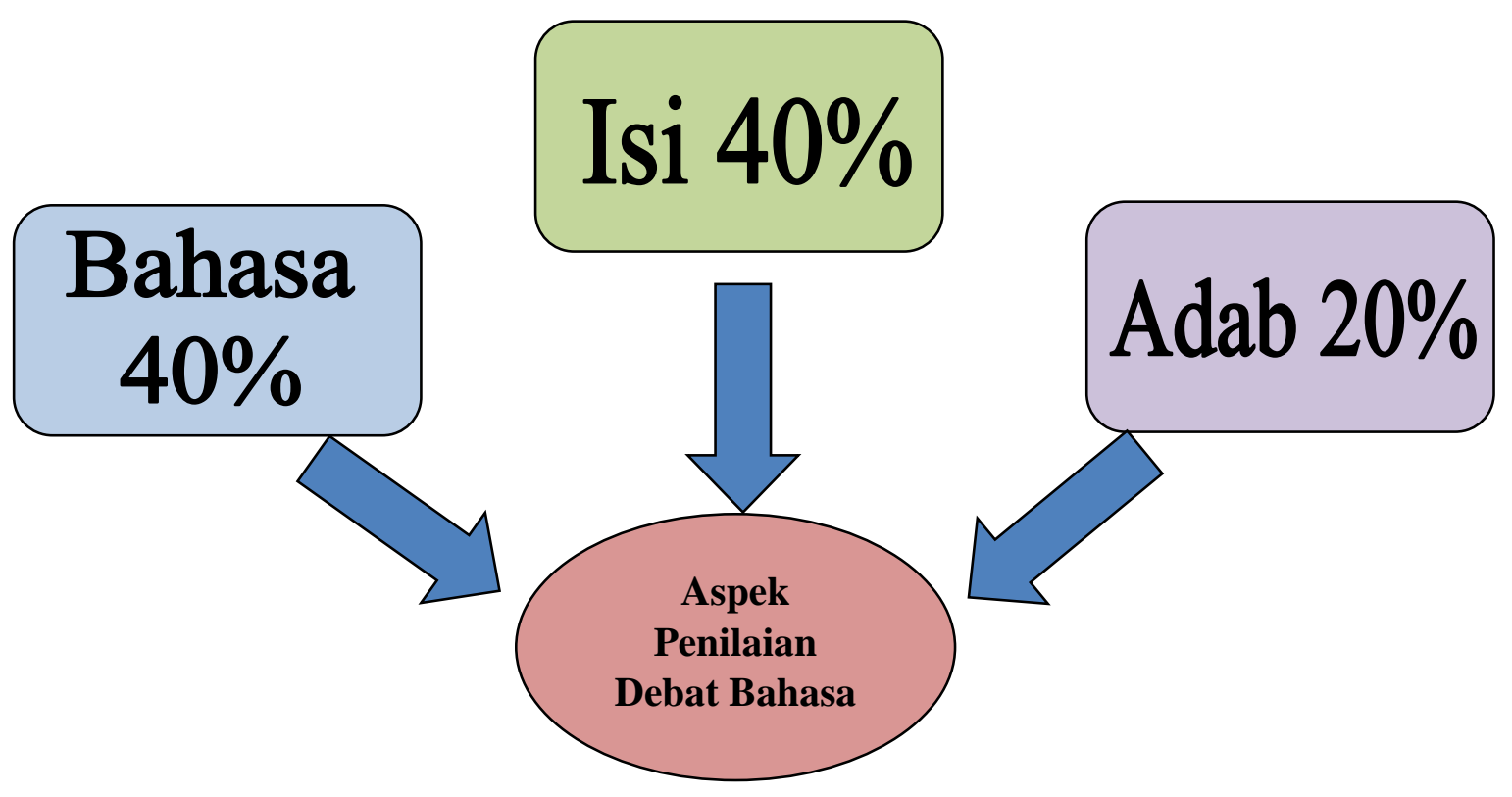




\section{Hasil dan Pembahasan Bentuk-bentuk kesalahan sintaksis dalam lomba debat Bahasa Arab}

Bentuk kesalahan yang terjadi pada perdebatan yang berlangsung di Surakarta jawa tengah terletak pada penggunaan dan pengamalan Inna Wa akhwatuha pada perlombaan debat bahasa Arab yang meraih juara 1 lomba debat Bahasa Arab Tingkat Mahasiswa se- Indonesia pada tangal 07 November 2017 yang bertempat di Surakarta, Jawa tengah. Adapun bentuk kesalahannya terletak pada lafadz عَلى أَنَّ مُجْتََْعُنا, jika di pandang dari kacamata sintaksis maka lafadz tersebut tidak sesuai dengan kaidah sintaksis yang berlaku, seharusnya lafadz عَلى أَنَنْ مُجْتَعَعْا tidak dibaca Rafa' (Dlommah) karena semua lafadz/ kalimat yang menjadi isimnya Inna Wa akhwatuha إنَ وأخواتها\{ Harus dibaca nashab dengan dasar Teori تتصب الإسم و ترفع الخبر (Menashobkan Isim/ mubtada' dan merafa'kan kepada Khobarnya inna wa Akhwatuha) maka seharusnya jika menyesuaikan dengan kaidah menjadi عَلَى أنَ مُجْنَتَعَنَا .

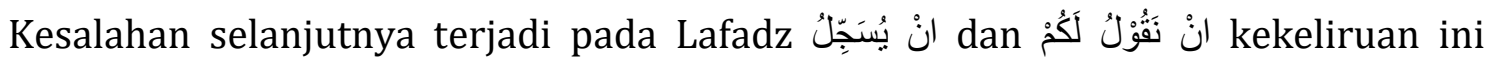
terjadi pada perdebatan yang terjadi antara Tim UM (A) Universitas Negeri Malang dan USIM (A) Universitas Sains Islam Malaysia, jika mengikuti kaidah maka setiap kalimat yang

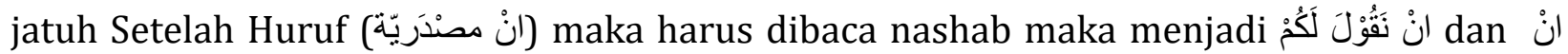
يُمَبِّلَ

Kesalahan selanjutnya terjadi pada lomba perdebatan yang berlangsung dipurwokerto tahun 2018, Adapun bentuk kesalahannya yaitu terletak pada sintaksis yaitu

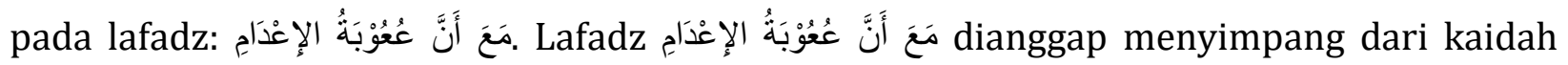
sintaksis karena seharusnya kalimat yang menjadi isimnya Inna Wa akhwatuha Harus dibaca nashab dengan dasar Teori تتصب الإسم و ترفع الخبر (Menashobkan Isim/ mubtada' dan merafa'kan kepada Khobarnya inna wa Akhwatuha). Berdasarkan teori tersebut

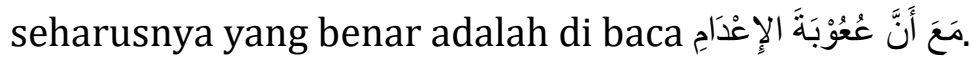

Kesalahan yang terjadi pada lomba mudzarah ilmiyah dalam event MQK (Musabaqah Qiraatul Kutub) TIM putra yang berlangsung di jepara pada tahun 2018 adalah

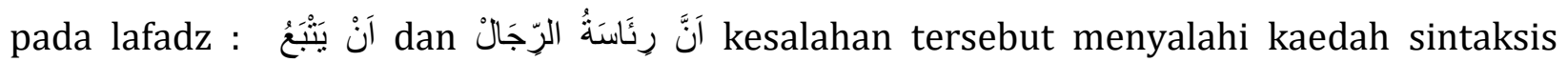
sebagaimana yang telah disebutkan di atas seharusnya kalimat yang menjadi isimnya Inna 
Wa akhwatuha تنصب الإسم و ترفع الخبر Harus dibaca nashab dengan dasar Teori (Menashobkan Isim/ mubtada' dan merafa'kan kepada Khobarnya inna wa Akhwatuha) dan setiap kalimat yang jatuh Setelah Huruf (انْ مصنَرَيَّة) maka harus dibaca nashab (Fathah),

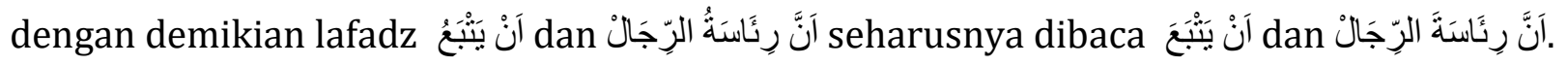

Bentuk kesalahan selanjutnya merupakan kesalahan sintaksis yang terjadi pada Final Debat Bahasa Arab Ihtifal IPT ASEAN 2018 UM A vs UIN SH Jakarta dengan judul نَحَنُ مِنَ الْفِرَقَقَت Adapun bentuk kesalahannya adalah : lafadz ,التحالف العسكري بين دول آسييا ضرورة

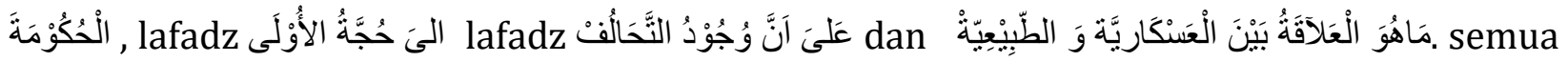

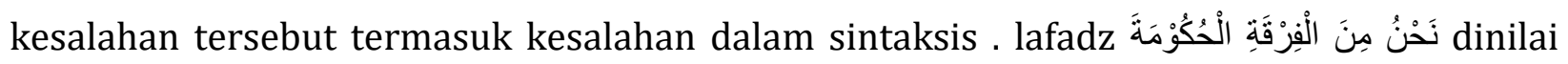
salah karena tidak sesuai dengan kaidah sintaksis seharusnya الُْكُوَْْة I'rab-nya juga dibaca

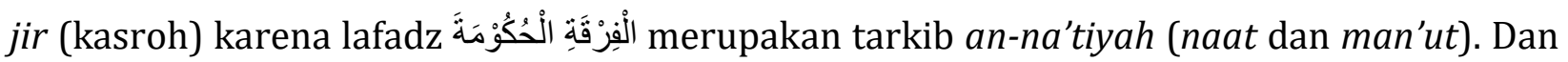
dalam aturan kaidah sintaksis Naat harus selalu mengikuti terhadap man'utnya dan di dalam aturan na'at dan man'ut maka harus sama di dalam empat hal :

a. Mufrad, tatsniyah, jama'

b. Mudzakkar, muannats.

c. Nakirah, ma'rifat.

d. I'rab.

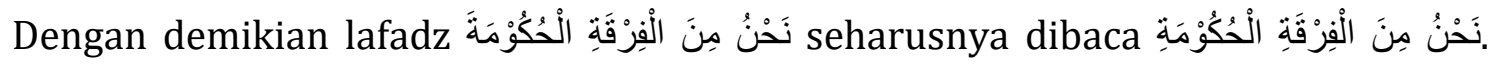

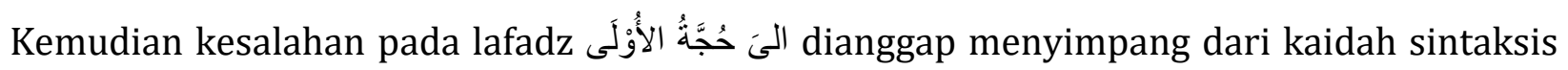
dikarenakan seharusnya kalimat/ lafadz yang jatuh setelah huruf jir maka i'rabnya dibaca

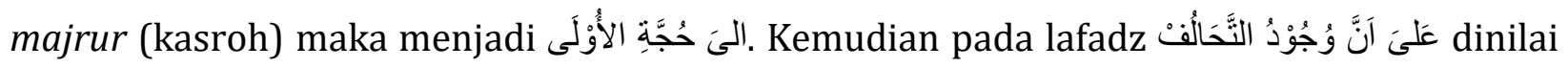
salah karena juga menyalahi aturan sintaksis sebaimana yang telah disebutkan diatas bahwa kalimat yang menjadi isimnya Inna Wa akhwatuha dengan dasar Teori تتصب الإسم و ترفع الخبر (Menashobkan Isim/ mubtada' dan merafa'kan kepada Khobarnya inna wa Akhwatuha) dengan demikian, maka lafadz yang benar adalah مَاهُ dianggap salah karena dlomir yang digunakan pada lafadz tersebut adalah dlomir Huwa (هو) sementara dlomir yang seharusnya digunakan adalah dlomir hiya (هي) karena yang ditanyakan adalah

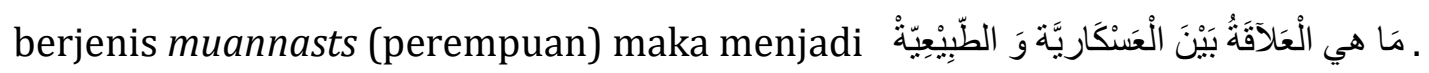


Kesalahan sintaksis ini terjadi di tengah hangatnya perdebatan antara kubu Pro dan kubu kontra yang terjadi antara FKA UGM UIN MALANG dan USIM Malaysia. Adapun

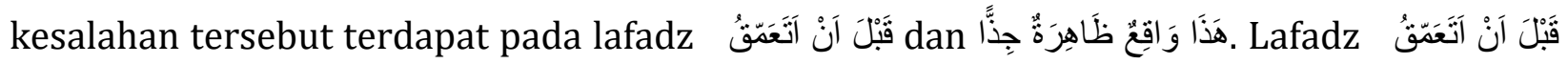
dianggap menyalahi aturan kaidah sintaksis karena setiap kalimat yang jatuh Setelah Huruf

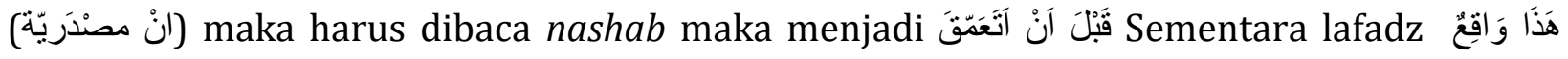

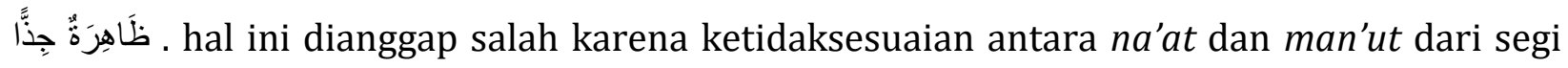

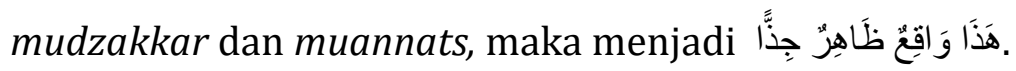

Kesalahan yang terjadi pada perdebatan sesi semi final antara SPBA sunan kalijaga melawan UAI (Universitas Al-Azhar Indonesia) dengan mosi perdebatan: Sistem Khilafah merupakan solusi untuk menciptakan peradaban islam Indonesia, kesalahannya terdapat pada lafadz سَوْتَ اَطُرَحُ جَمْيًْا. Lafadz سَوْفَ اَطَرَحُ جَمَيْعًا dianggap menyimpang dari kaidah sintaksis karena seharusnya Mutanadzir (Debater) tidak menggunakan kata سوَفَ namun cukup menambahkan huruf س saja atau bahkan tidak usah sama sekali, sebab, fi'il mudlori' secara mutlak sudah memiliki arti sedang atau yang akan datang, namun apabila menggunakan kata سوَّف maka menunjukkan arti masa yang jauh. Sebagaimana yang telah disebutkan oleh Dr. H. Abdul Haris di dalam Kitabnya, bahwa: salah satu ciri dari kalimat fi'il adalah menunjukkan arti akan dan masa terhadinya adalah dekat (للقريب juga memiliki arti akan namu masa terjadinya menunjukkan makna jauh (للبعيد) (Abdul Haris: 34). Dengan demikian mengapa lafadz سوَفَ dianggap kurang benar, maka penggunaan kata yang benar adalah اَطَرَحُح حَمْنِعًا ساطَطْرَح جَمْيْعًا.

Kesalahan selanjutnya terjadi ditengah-tengah panasnya perdebatan antara kubu pro dan kontra yang merupakan delegasi dari universitas UIN malang Indonesia melawan universitas Swedia dengan mosi debat: يَرى هذا المجلس على ان الدول الديمقر اطية جعل التصويت إجباري

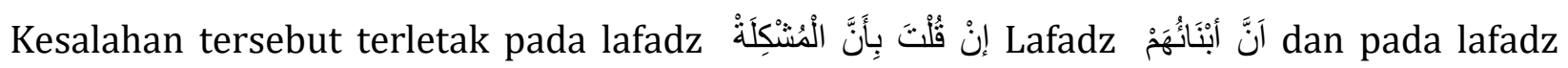

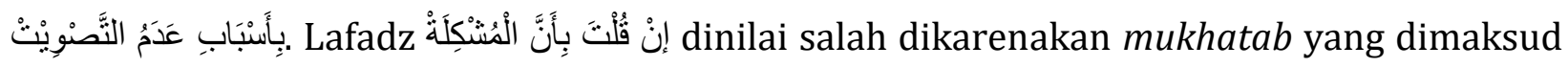
saat perdebatan adalah seorang perempuan maka seharusnya tidak menggunakan dlomir

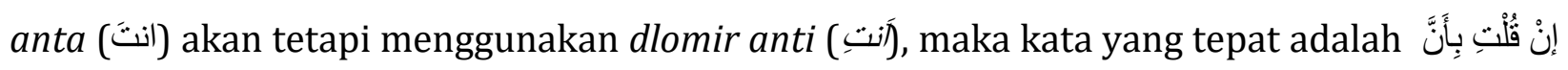

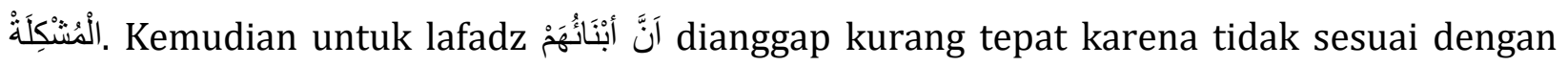
kaidah sintaksis, seharusnya kalimat yang menjadi isimnya Inna Wa akhwatuha Harus dibaca nashab dengan dasar Teori تنصب الإسم و ترفع الخبر (Menashobkan Isim/ mubtada' 
dan merafa'kan kepada Khobarnya inna wa Akhwatuha) maka lafadz yang benar adalah

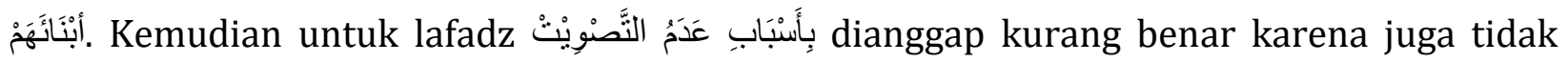

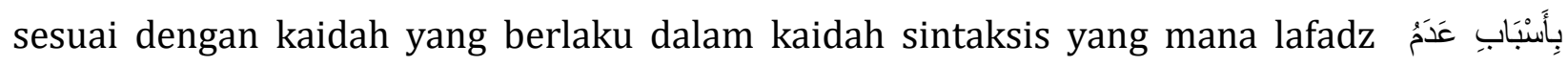

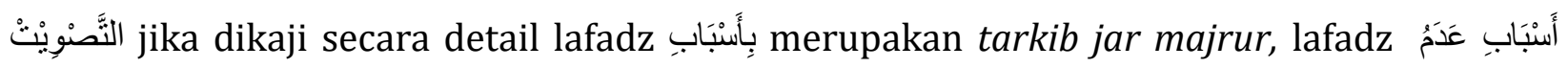

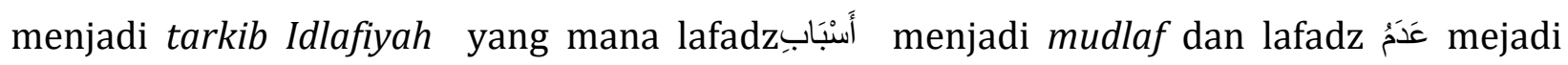
mudlaf ilaihi dan seharusnya mudlaf ilaihi itu seharusnya dibaca jir dan begitu juga dengan lafadz عَدَمُ النَّصْوِيْتِ merupakan tarkib idlafiyah, maka seharusnya lafadz tersebut dibaca

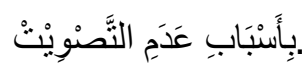

Kesalahan pada perlombaan debat Bahasa Arab pada sesi Final PIONIR IX 2019 delegasi kubu Pro (UIN Syarif Hidayatullah dan UIN Sunan Kalijaga Jogjakarta) kubu kontra ( UIN Maulana Malik Ibrohim Malang dan UIN Sunan Gunung Jati Bandung) terdapat pada

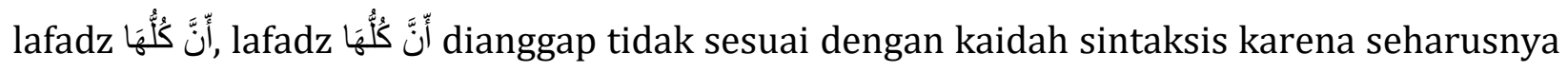
isimnya Inna Wa akhwatuha تنصب الإسم Harus dibaca nashab dengan dasar Teori (Menashobkan Isim/ mubtada' dan merafa'kan kepada Khobarnya inna wa Akhwatuha) maka menjadi أنَّنَ كُلَّهَا.

Kesalahan yang terjadi dalam lomba debat Bahasa Arab pada event Festifal Arab Nusantara antara SPBA UIN sunan Kalijaga Vs FDI UIN Jakarta dengan mosi "Majelis percaya bahwa dana desa tidak mampu mengurangi jumlah kemiskinan" Adapun kesalahan

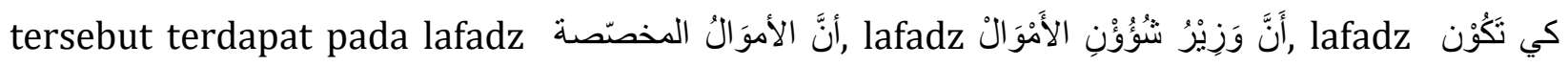

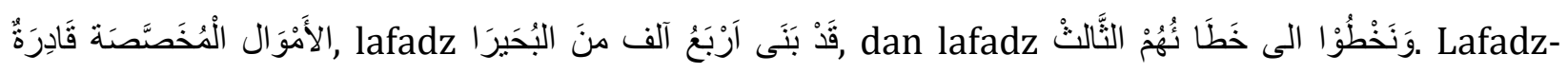
lafadz tersebut dianggap kurang tepat karena menyimpang dari kaidah sintaksis, pada

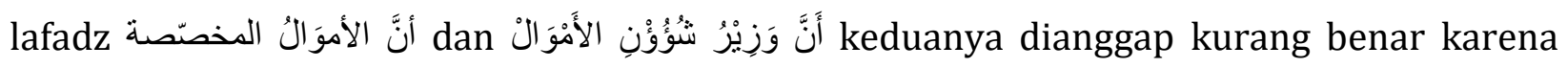
seharusnya isimnya Inna Wa akhwatuha Teori تنصب الإسم و ترفع الخبر (Menashobkan Isim/ mubtada' dan merafa'kan kepada Khobarnya

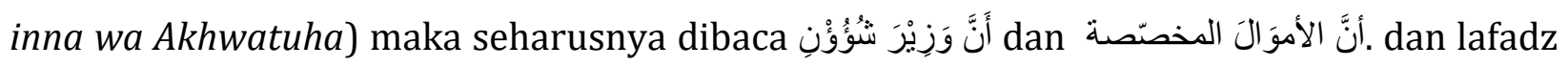

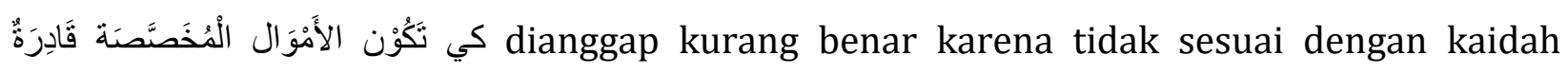
كان واخواتها sintaksis seharusnya kalimat yang menjadi khobarnya kana wa akhwatuha yang memiliki Amal ترفع الإسم وتتصب الخبر (Merofa'kan isim dan menashobkan khobarnya),

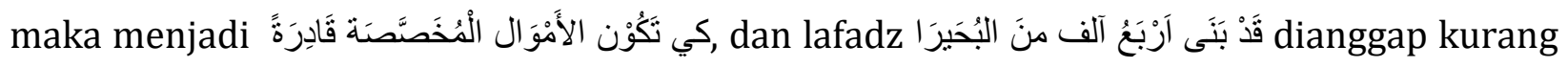
benar karena tidak sesuai dengan kaidah sintaksis , yang mana seharusnya pada kalimat بَنَى yang berkedudukan sebagai maf'ul biih maka seharusnya dibaca nashab. Maka menjadi 


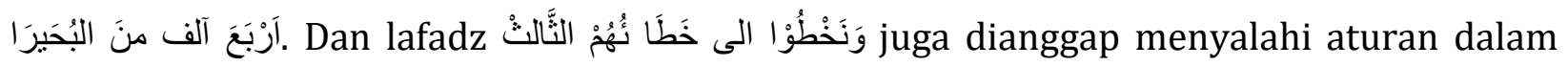
kaidah sintaksis karena seharusnya setiap kalimat/ lafadz yang jatuh setelah huruf jir

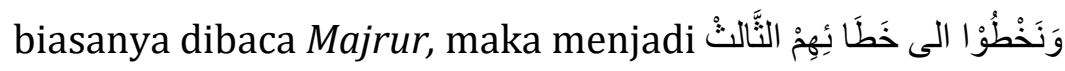

Kesalahan yang terjadi di dalam sebuah event perdebatan FJA (Festifal jazirah Arab) 2020 pertandingan antara IIUM Malaysia Vs Al- Mutla USIM Malaysia, Adapun

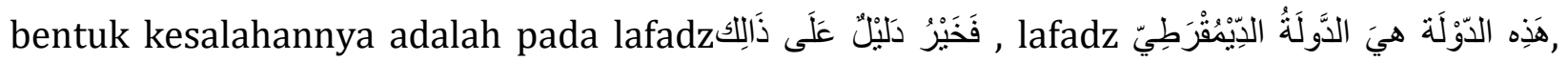

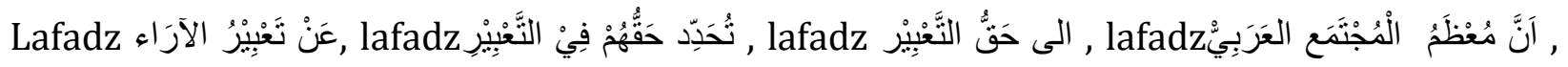

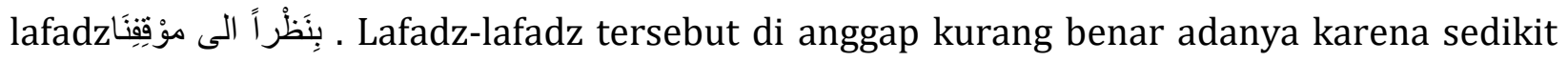

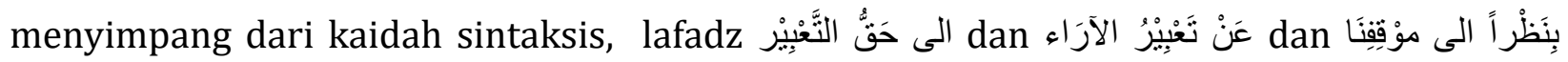
dianggap menyimpang dari kaidah sintaksis karena lafadz tersebut setelah huruf jiir tidak dibaca majrur, maka bila disesuaikan dengan aturan yang benar adalah setiap ada kalimat yang jatuh setelah huruf jir maka di pastikan dibaca majrur, maka bacaan yang benar

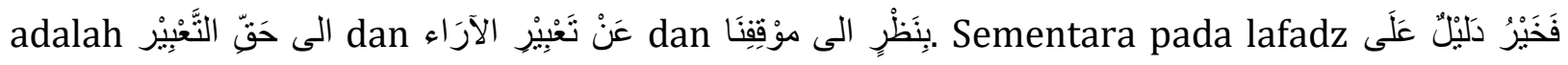
ذَالِِdi anggap kurang benar karena seharusnya kalimat yang kedudukannya menjadi Mudlof

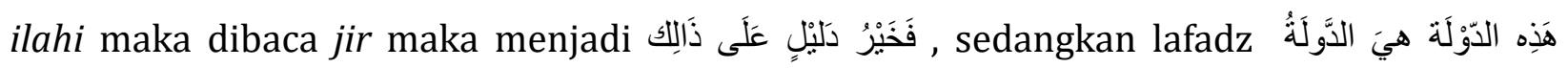
merupakan tarkib na'tiyyah yang mana dalam aturan kaidah sintaksis Naat harus selalu mengikuti terhadap man'utnya dikarenakan man'ut pada kalimat tersebut adalah

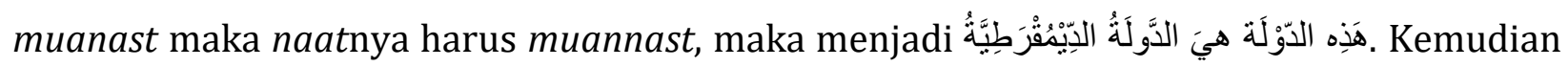

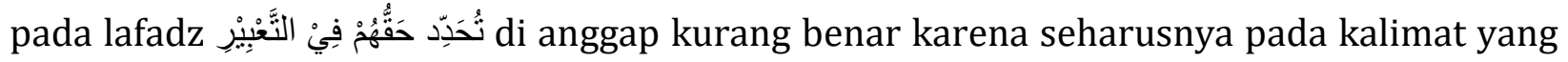

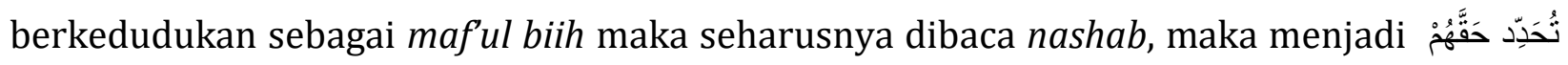
فِفيْ النَتَبِيْرِ

\section{Bentuk-bentuk kesalahan morfologi dalam lomba debat Bahasa Arab}

Pada event perdebatan yang diadakan oleh UM, salah satu contoh lafadz yang terjadi kesalahan pada bidang Morphology yakni pada lafadz :

\section{بأنه يقول Bahwasanya Ia Sedang Mengatakan}

Padahal seharusnya lafadz yang benar adalah menggunakan jenis Fi'il Madhi Dari kata قَّلَ yaitu Lafadz sebab kejadiannya pembicara ke-2 mengatakan hal ini setelah pembicara pertama mengatakan dan memberika hujjah, maka penggunaan waktu yang tepat adalah menggunakan fi'il madhi قَّ Hal ini didasari dengan kaidah yang apabila 
waktunya telah lampau atau telah terjadi maka harus menggunakan Fi'il Madhi. Fi'il madhi itu sendiri memiliki arti pekerjaan yang telah lampau.

افعالهم ثلآثة في الو اقع ماضى وفعل الأمر و المضار ع.Faidurrahman: 2011)

Dalam Literartur lain di katakana tentang pengertian Fi'il Madhi Bahwa: Fi'il Madhi adalah Fiil yang menunjukkan arti pekerjaan yang telah lampau. Contoh lafadz قال disebut sebagai Fí'il Madhi sehingga ia Memiliki zaman Lampau. Arti lafadz قال adalah telah berkata. Ciri-ciri Fi'il Madhi adalah dapat di masuki ta'ta'nis Sakinah (الساكنة التأنيث) contoh قَالتُ yang memiliki arti Dia perempuan telah berkata selain di maksuki oleh ta' ta'nis maka di masuki pula oleh lafadz

Bentuk kesalahan morphology pada event perlombaan debat kali ini adalah kesalahan dalam penggunaan Masdar (Geround) yakni pada lafadz:

$$
\text { لتنتاقَشَنَ و تنََظَرَ }
$$

Pada Tanggal 1 mei 2018 salah seorang debater yang sedang tampil dalam event perdebatan melakukan kesalahan pada bidang morfology. Ia mengucapkan Lafadz لتناقَشَ و

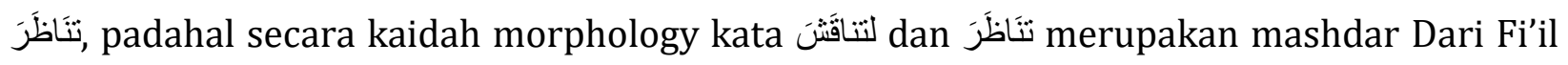

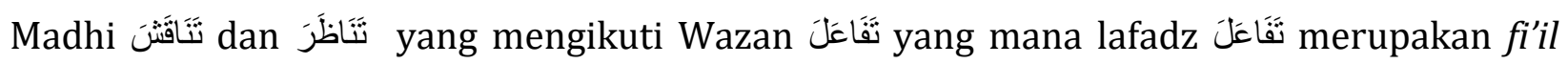
Tsulasi Mazin Khumasi dengan tambahan hutuf (ت) dan ('), maka yang benar seharusnya

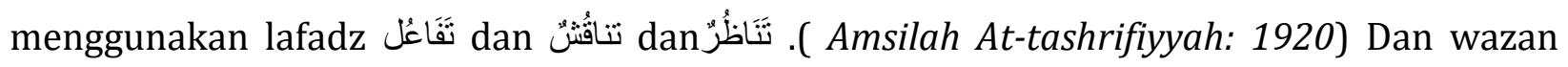
memiliki banyak Faedah salah satu di antaranya adalah lil musyarakah baina AlIstnaini (تلمشاركة بين الإثنين) contoh : تلمد ريد و عمرو yang artinya zaid dan amr saling menjauh

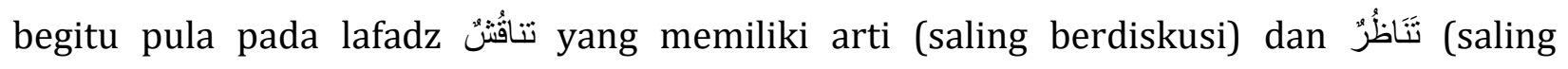
berdebat). (ابي حامد محمد ابن القاضي: 2012 ( )

Bentuk kesalahan morphology dalam event Lomba debat Bahasa Arab ini penyalahgunaan Dlomir (Kata Ganti) yang terletak pada fiil amar, seperti kesalahan yang terjadi pada MC (master Of Ceremony), pertandingan debat jemputan Nusantara USIM (universitas Sains Islam Malaysia), bentuk kesalahan Morphologhy adalah apada Lafadz فالتتفضل مشكور ini kurang فika dikaji secara Kaidah Morphologhy maka lafadz فالتفضل مشكورا tepat jika diperuntukkan untuk mutanadziroh sebab dan secara kebetulan pada MC (master Of Ceremony) saat mengucapkan lafadz فالتنفضل مشكور ini diperuntukkan untuk Seorang perempuan karena pada saat itu MCnya mempersilahkan sesorang perempuan untuk 
menyampaikan pendapatnya, dan hal ini jika dipandang secara kacamata Morphologhy kurang tepat karena seharusnya fi'il amar (kata perintah untuk perempuan) maka harus di tambah dengan Ya' Muannast Mukhotobah (باء المؤنثة المخاطبة) yang mana Ya'Muannast Mukhotobah merupakan ya' yang menunjukkan perempuan yang di ajak bicara, ya' Muannast Mukhotobah dapat masuk pada dua Fi'il yaitu:

\section{1) Fi'il Mudlari'}

Contoh : تَضربين pada lafadz ini memiliki arti "Kamu Perempuan sedang atau akan memukul"

2) Fi'il amar

Contoh: pada Lafdz إضْربي memiliki arti "memukullah kamu perempuan" فالتتفضل مشكورا Berdasarkan dasar-dasar tersebut, sudah jelas secapa pasti maka pada lafadz jika yang menjadi mukhothob adalah seorang perempuan maka harus ditambah dengan ya' Muannast Mukhotobah (ياء المؤنثة المخاطبة) maka menjadi فتتفضلي مشكور. (Abdul haris: 2018).

kesalahan selanjutnya merupakan kesalahan pada bentuk Morfology, kekeliruan ini terjadi dalam perdebatan antara UNIDA dan UIN MALANG pada event Mahrojan Al-

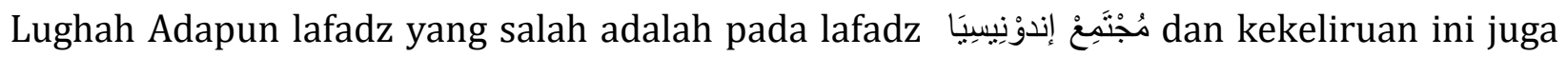
terjadi pada Lomba perdebatan Bahasa Arab Antara UIN dan UM dengan Qodiyyah atau Judul perdebatan : التخالف العكري بين دول آسييا ضرورة kesalahan tersebut berada pada lafadz

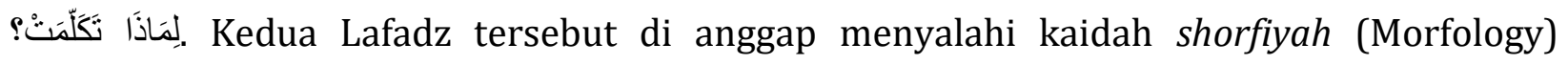

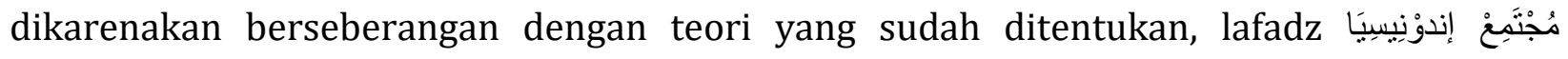
dianggap menyimpang dari kaidah Morfologi karena searusnya tidak menggunakan lafadz

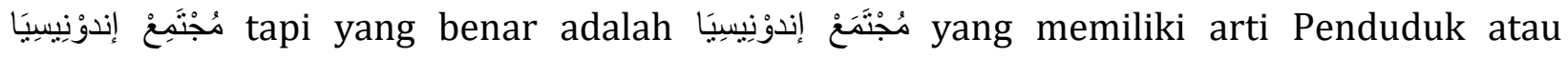

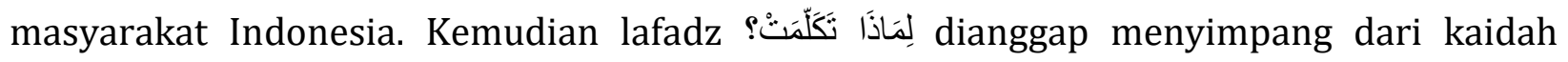
shorfiyyah atau Morfologi karena tidak sesuai dengan teori yang berlaku, pada lafadz لِحَاذَا نَكَّكَتْْْ dianggap salah karena yang mukhotob yang dituju ada didepan mata (tampak) dan Ia

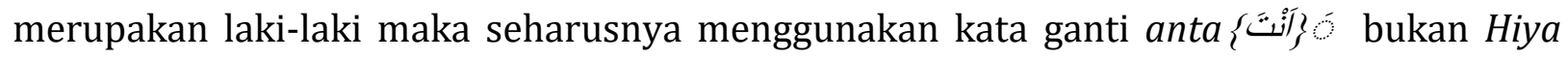

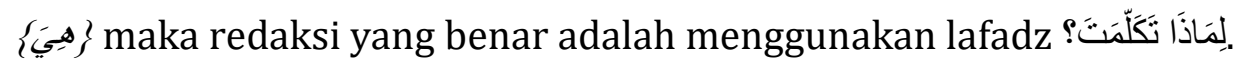

Kesalahan morfologi yang terjadi pada lomba mudzarah ilmiyah dalam event MQK (Musabaqah Qiraatul Kutub) TIM putra yang berlangsung di jepara pada tahun 2018 adalah

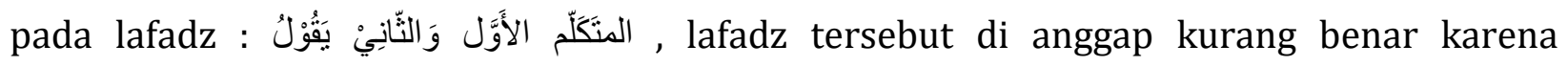


mutanadzir mengatakan lafadz tersebut pada mukhatab (lawan bicara) yang kejadiannya sudah lampau atau sudah berlalu, maka seharusnya tidak menggunakan makna sedang atau yang akan datang (Fi'il mudlari') namun menggunakan makna lampau (fiil madli)

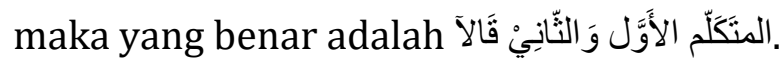

Kesalahan Morfology selanjutnya terjadi ditengah-tengah panasnya perdebatan antara kubu pro dan kontra yang merupakan delegasi dari universitas UIN malang Indonesia melawan universitas Swedia dengan mosi debat: يَرى هذا الججلس على ان الدول الديمقراطية

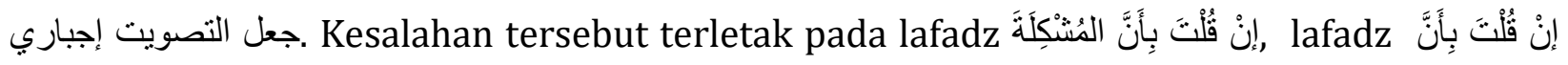
dianggap kurang benar ketika dikaji dari segi morfologynya dikarenakan yang dituju atau yang dimaksud adalah perempuan, dan ketika menggunakan kata ganti (أَنَ) maka kurang tepat, jika yang dimaksudkan atau yang menjadi lawan bicaranya adalah seorang

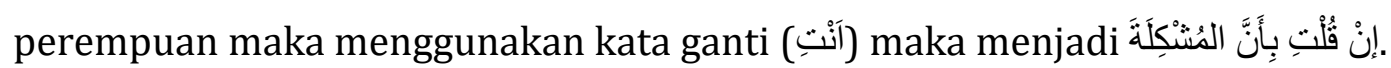

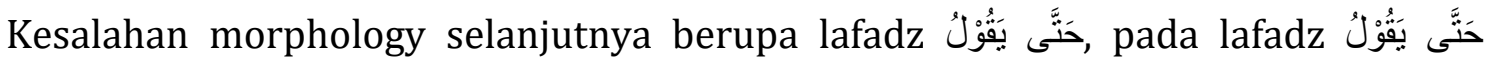
seharusnya lafadz yang benar adalah menggunakan jenis Fi'il Madhi Dari kata يقول yaitu Lafadz قَالَ, sebab kejadian hal ini mengandung makna lampau, maka penggunaan waktu yang tepat adalah menggunakan fi'il madhi قَّلَ. Hal ini didasari dengan kaidah yang apabila waktunya telah lampau atau telah terjadi maka harus menggunakan Fi'il Madhi. Fi'il madhi itu sendiri memiliki arti pekerjaan yang telah lampau. Maka redaksi yang benar seharusnya

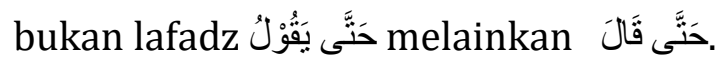

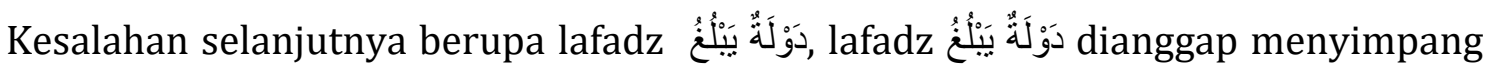

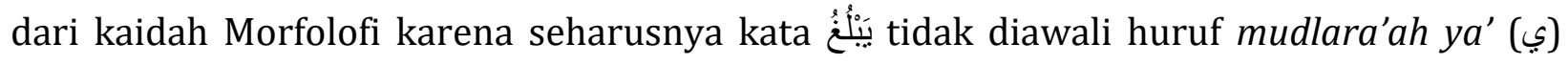
namun di dahului oleh huruf mudlara'ah $t a^{\prime}$ (توَلَةٌ yang mana Ia merupakan lafadz yang berjenis Muannast maka redaksi yang benar adalah:

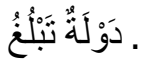

لأَنَّ الحُكُمَة lafadz, الحكومة يُقَدَمُ Kesalahan morphology selanjutnya terletak pada lafadz

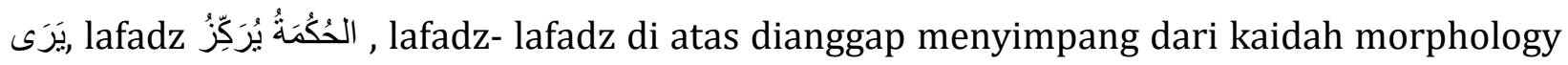

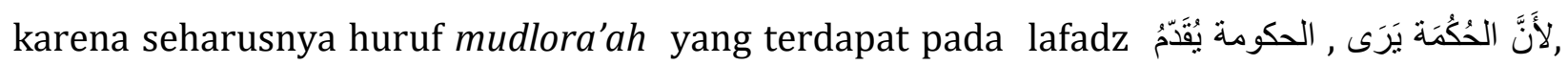

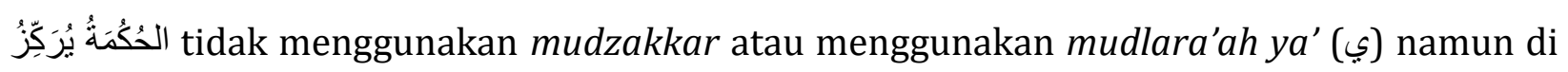

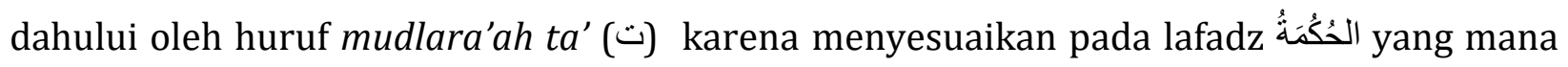

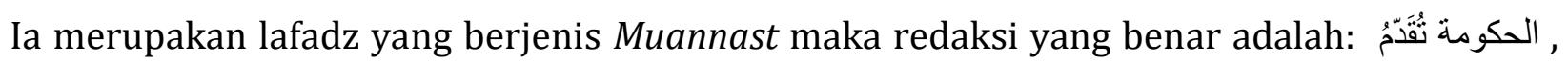

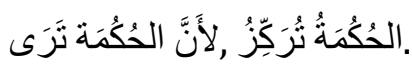


Berikut adalah tabel bentuk kesalahan sintaksis dan morfologi dalam lomba debat: 


\begin{tabular}{|c|c|c|c|c|}
\hline \multicolumn{5}{|c|}{ BENTUK-BENTUK KESALAHAN SINTAKSIS (NAHWIYAH) DALAM KETERAMPILAN } \\
\hline \multicolumn{5}{|c|}{ DEBAT BAHASA ARAB (MUNADZARAH) } \\
\hline NO & BENTUK KESALAHAN & KOREKSI & LINK VIDEO & TAHUN \\
\hline 1 & 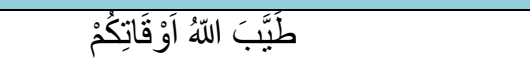 & 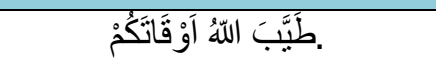 & https://youtu.be/Bd5Uo_tE-mA & 2012 \\
\hline 2 & عَلى أنَّ مُجْنَمَعْنا & عَلَى أنَ مُجْنَمَعَنَا & https://youtu.be/at1UIAfHad4 & 2017 \\
\hline 3 & انْ يُسَجِجِلُ & انْ يُسَجِجِلَ & https://youtu.be/SrtWlwTMUwY & 2014 \\
\hline 4 & 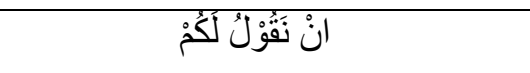 & انْ نَقُقْ لَلَ لَكْمْ & https://youtu.be/SrtWlwTMUwY & 2014 \\
\hline 5 & 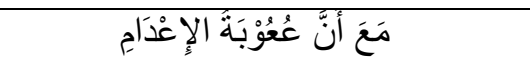 & 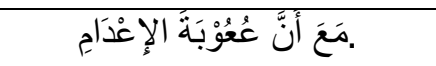 & https://youtu.be/q397JnIIxSg & 2018 \\
\hline 6 & 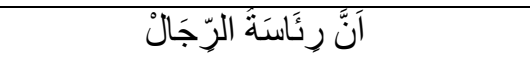 & اََنَّ رِئَاسَةًَ الرِّجَالْ & https://youtu.be/0w7cxFHm0RQ & 2018 \\
\hline 7 & 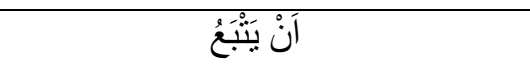 & اََنْ يَتْبَعَ & https://youtu.be/0w7cxFHm0RQ & 2018 \\
\hline 8 & 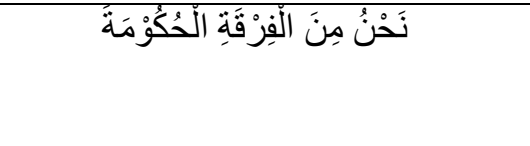 & 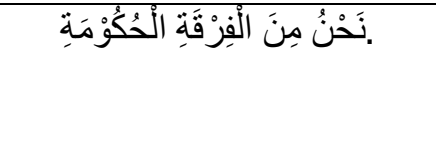 & $\begin{array}{l}\text { https://youtu.be/thF3oWApFZY dan } \\
\underline{\text { https://youtu.be/Qyx8TzWJp08 }}\end{array}$ & 2018 \\
\hline 9 & اللََ حُجَّةُ الأوْلَى & الَيَ حُجَّةِة الأوْلَى & $\begin{array}{c}\text { https://youtu.be/thF3oWApFZY dan } \\
\underline{\text { https://youtu.be/Qyx8TzWJp08 }}\end{array}$ & 2018 \\
\hline 10 & عَلََّ اََنَّ وُجُوْْدُ التِّحَالَفْ & 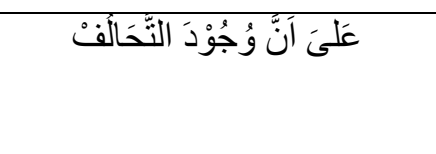 & $\begin{array}{c}\text { https://youtu.be/thF3oWApFZY dan } \\
\underline{\text { https://youtu.be/Qyx8TzWJp08 }}\end{array}$ & 2018 \\
\hline 11 & 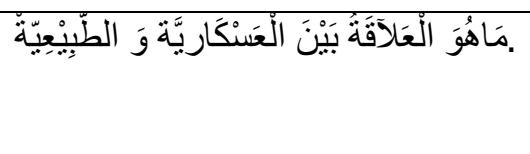 & 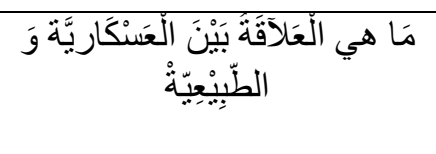 & $\begin{array}{c}\text { https://youtu.be/thF3oWApFZY dan } \\
\underline{\text { https://youtu.be/Qyx8TzWJp08 }}\end{array}$ & 2018 \\
\hline 12 & 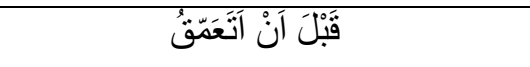 & 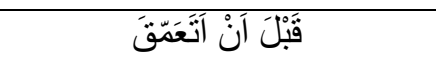 & https://youtu.be/RyVANy0xjNw & 2018 \\
\hline
\end{tabular}




\begin{tabular}{|c|c|c|c|c|}
\hline 13 & 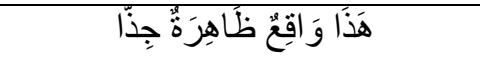 & 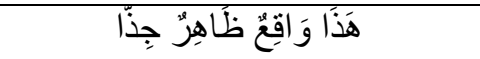 & https://youtu.be/RyVANy0xjNw & 2018 \\
\hline 14 & سَوْفَ أَطْرَحُ جَمْيْعًا & ساَطْرَحُ جَمْيْعًا & https://youtu.be/JkwZ09JPdPo & 2019 \\
\hline 16 & 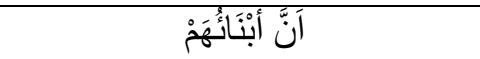 & 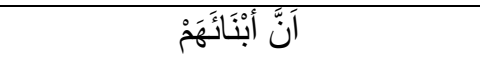 & https://youtu.be/Z6PHFq_fstY & 2019 \\
\hline 17 & بِأُسْبَابِ عَدَمُ النَّصنوِيْتِتْ & 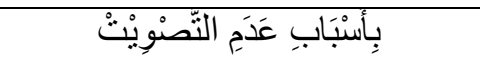 & https://youtu.be/Z6PHFq_fstY & 2019 \\
\hline 18 & أَنَّ كُلْهَها & أَنَّ كَلْهَها & https://youtu.be/6TxzwsE3qX0 & 2019 \\
\hline 19 & أَنَّ الأموَ الَُ المخصتصنة & أَنّْ الأموَالَ المخصّصة & https://youtu.be/1Czi_Q_fNgE & 2019 \\
\hline 20 & أَنَّ وَزَِيْرُ شُوُؤُوْنِ الأْمَوَالْ & أَنَّ وَزِْيْرَ شُوُوُوْْنِ الأْْوَالْ & https://youtu.be/1Czi_Q_fNgE & 2019 \\
\hline 21 & 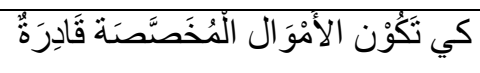 & 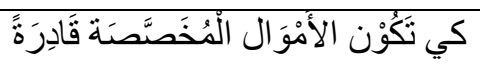 & https://youtu.be/1Czi_Q_fNgE & 2019 \\
\hline 22 & قَذْْ بَنَى اََرْبَعُ آلف منَ الُْحَيرَا & 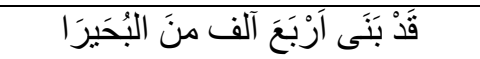 & https://youtu.be/1Czi_Q_fNgE & 2019 \\
\hline 23 & 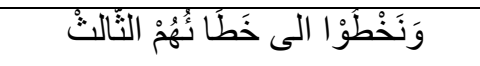 & 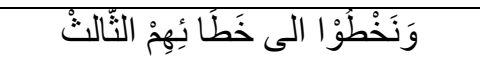 & https://youtu.be/1Czi_Q_fNgE & 2019 \\
\hline 24 & الَى حَقُّ النُّْبِيْرِ & 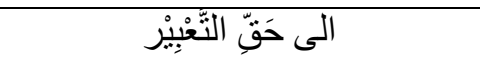 & https://youtu.be/V-1ur02gazg & 2020 \\
\hline 25 & عَنْ تَعَبْيِرُ الآرَاء & عَنْ تَعَبِيْرِ الآرَاء & https://youtu.be/V-1ur02gazg & 2020 \\
\hline 26 & 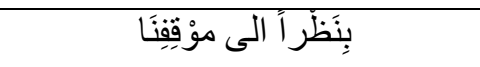 & بِنَظْرِ الى مؤقِقِنَا & https://youtu.be/V-1ur02gazg & 2020 \\
\hline 27 & 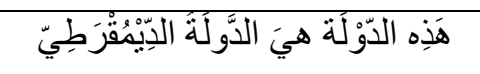 & 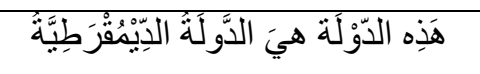 & https://youtu.be/V-1ur02gazg & 2020 \\
\hline 28 & 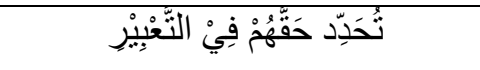 & 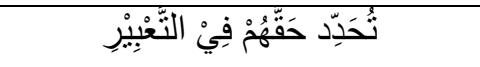 & https://youtu.be/V-1ur02gazg & 2020 \\
\hline 29 & فَفَخْيرُ دَلَيْلِ عَلَى ذَالِلِك & فَخَبْرُ دَلَّلٍْ عَلَى ذَالِلِك & https://youtu.be/V-1ur02gazg & 2020 \\
\hline
\end{tabular}

\section{BENTUK-BENTUK KESALAHAN MORFOLOGY (SHARFIYAH) DALAM KETERAMPILAN}




\begin{tabular}{|c|c|c|c|c|}
\hline \multicolumn{5}{|c|}{ DEBAT BAHASA ARAB (MUNADZARAH) } \\
\hline NO & BENTUK KESALAHAN & KOREKSI & LINK VIDEO & TAHUN \\
\hline 1 & بأنه يقول & بأنها قَالَ & https://youtu.be/0rxjgBs3jPk & 2015 \\
\hline 2 & 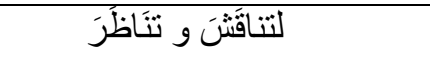 & لت لتناقُشَ و نتَاظَرَ & https://youtu.be/q397JnIIxSg & 2018 \\
\hline 3 & فالتتفضل مشكوراً & فالتتفضئليْ مشكوراً & https://youtu.be/Bd5Uo_tE-mA & 2012 \\
\hline 4 & مُجْتَمِعْ إندوَْنِيِِيًَا & مُجْتَمَعْ إندوْْنِيسِيَا & https://youtu.be/M5lnYfn1i6Y & 2017 \\
\hline 5 & 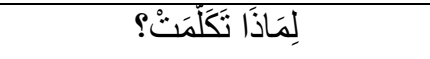 & 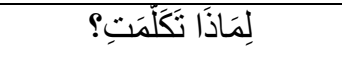 & https://youtu.be/M5lnYfn1i6Y & 2017 \\
\hline 6 & 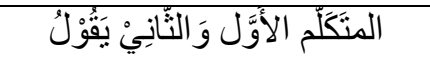 & المنَكَلْم الأوَّل وَالثَانِيْ قَالَا & https://youtu.be/0w7cxFHm0RQ & 2018 \\
\hline 7 & 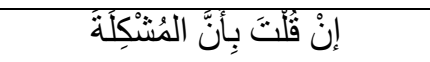 & 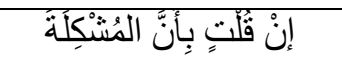 & https://youtu.be/Z6PHFq_fstY & 2019 \\
\hline 8 & حَنّْى يَقُوْلُ & حَتُّى قَالَ & https://youtu.be/6TxzwsE3qX0 & 2019 \\
\hline 9 & 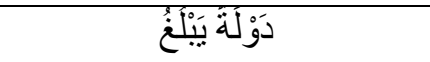 & 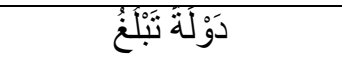 & https://youtu.be/kjeJnOqh6w4 & 2019 \\
\hline 10 & 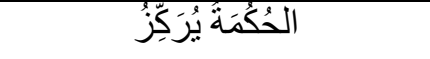 & 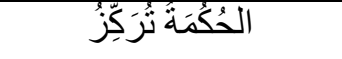 & https://youtu.be/1Czi_Q_fNgE & 2019 \\
\hline 11 & الحكو مة يُقَدَّمُ & الحكومة تُقَلَّمُ & https://youtu.be/1Czi_Q_fNgE & 2019 \\
\hline 12 & لأنَّ الحُكُمَتة يَرَى & لأنَّ الحُكُمَتَة يَرَى & https://youtu.be/1Czi_Q_fNgE & 2019 \\
\hline
\end{tabular}




\section{Solusi mengatasi kesalahan sintaksis dan morfologi pada lomba debat bahasa arab}

Hakikat bahasa adalah komunikasi. Dalam berdebat pun, kita (dalah bahasa jurnal ilmiah tiak mengenal bahasa kita, kamu dll, mestinya diganti dengan detater atau pendebat dll) harus bisa memberi pemahaman yang jelas terhadap pihak lawan begitu juga sebaliknya, Komunikasi erat kaitannya dengan bunyi dan ucapan yang dilafalkan. pelafalan atau ucapan yang salah atau tidak tepat akan menimbulkan perbedaan makna atau kesalahan arti. Berikut ini penulis mencoba memformulasikan solusi dari kesalahan dalam keterampilan berbicara debat bahasa Arab: (1) sebaiknya para debaters mempersiapkan dengan benar materi yang akan di sampaikan dengan memperhatikan aspek sintaksis dan morfologi nya, sehingga mampu menyampikan materi dengan benar tanpa menimbulkan perbedaan makna dan kesalahpahaman arti, (2) Memperkaya dan meng-upgrade diri dalam memahami ujaran materi yang akan disampaikan tentunya tidak luput dari latihan berkesinambungan, diantara nya seringnya latihan berbicara didepan umum untuk melatih kepercayaan diri dan memperbanyak bacaan seputar perekonomian, politik, pendidikan, isu-isu hangat internasional dan lain-lain sebagainya, dan (3) Meningkatkan keseriusan mendalami debat bahasa Arab dengan adanya motivasi dari diri sendiri yang kuat.

\section{Kesimpulan}

Dalam penelitian ini ditemukan kesalahan sintaksis pada video lomba debat bahasa arab tingkat nasional dan ASEAN berupa penyimpangan penggunaan inna wa akhwatuhaa pada 7 video, penyimpangan huruf jer pada 4 video, penyimpangan an mashdariyah pada 3 video, penyimpangan penggunaan dhamir pada 2 video dan masingmasing 1 video pada penyimpangan huruf sin dan saufa, mudhaf ilaih, kaana wa akhwatuhaa, na'at man'ut dan maf'ul bih. Dan ditemukan kesalahan morfologi berupa penyimpangan penggunaan fi'il mudhori' pada 3 video, penggunaan fi'il madhi' pada 2 video dan masing-masing 1 video pada penyimpangan mashdar (geround), wazan dan fi'il amr. Dengan adanya penelitian ini diharapkan agar para debaters dapat selalu mengevaluasi diri dan untuk lebih mempersiapkan diri dalam aspek sintaksis dan morfologi, melakukan latihan berkesinambungan dan meningkatkan keseriusan mendalami debat bahasa Arab. 


\section{Referensi}

Jannah, Fithrotul. "Pembelajaran Debat Bahasa Arab Melalui Model International Universities Arabic Debating Championship (IUADC), Qatar." Prosiding Konferensi Nasional Bahasa Arab III (Oktober 2017): 216-223.

Suharto, Toto. "Analisis Kesalahan Sintaksis dalam Buku Teks Bahasa Arab Untuk Perguruan Tinggi Keagamaan Islam." Arabiyat Vol 4 No 1 (April 2017): 20-37.

Fahmi, Khairulrijal. "Analisis Kesalahan Gramatikal Teks Terjemah (Indonesia-Arab) dalam Pendidikan Bahasa Arab." Kordinat Vol XV No 1 (April 2016): 105-116.

Wulandari, Nawang. "Analisis Kesalahan Fonologis dalam Keterampilan Berbicara Bahasa Arab." Al-Fathin Vol 3 No 1 (Januari 2020): 71-84.

Salim, Nur. 2016. Analisis Kesalahan berbahasa pada Kitabah Siswa Kelas X MA Ta'mirul Islam Solo dan MAU Al-Imdad Jogjakarta Tahun Ajaran 2015-2016. (Thesis). Jogjakarta. UIN Sunan Kalijaga Jogjakarta.

Haniah. "Analisis Kesalahan Berbahasa Arab pada Skripsi Mahasiswa Jurusan Bahasa dan Sastra Arab." Arabi Vol 3 No 1 (2018): 23-34.

Amriani. "Pengaruh Ilmu Ashwat Terhadap Keterampilan Berbicara Mahasiswa Pendidikan Bahasa Arab di IAIM Sinjai." Jurnal Kajian Pendidikan dan Bahasa Arab Vol 2 No 2 (Oktober 2020):

Setianingsih, Siska. "Pengaruh Metode Debat Terhadap Keterampilan Berbicara Siswa." Bina Gogik Vol 7 No 2 (September 2020): 55-64.

Burdah, Ibnu. 2018. Melejitkan Kemampuan Bahasa Arab Aktif Melalui Strategi Debat. Malang: CV Lisan Arabi.

Haris, Abdul. 2018. Teori dasar Nahwu \& Sharf. Jember: Al-bidayah.

Rahman, Faidur. 2011. Tashilatun Nafi'in. Madura: PP. An-Nafi'iyyah.

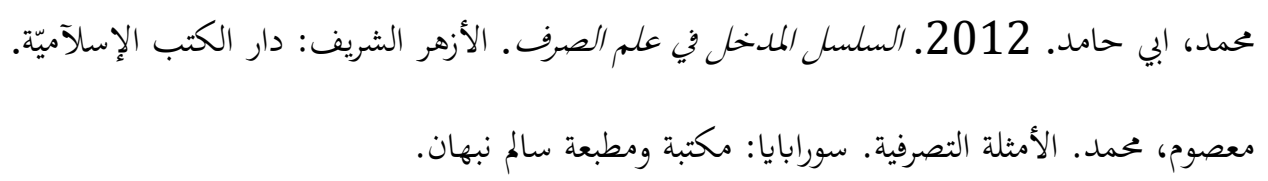

www.youtube.com 